\title{
JUDICIAL REACTION TO CHANGE: THE CALIFORNIA SUPREME COURT AROUND THE 1986 ELECTIONS
}

\author{
Nicholas L. Georgakopoulos $\dagger$
}

INTRODUCTION . ........................ 405

I. THE BACKDROP FOR THE CALIFORNIA JUDICIAL ELECTIONS OF $1986 \ldots \ldots \ldots \ldots \ldots \ldots \ldots \ldots \ldots \ldots, 408$

II. CONSISTENCY BETWEEN 1984 AND 1989 ......... 416

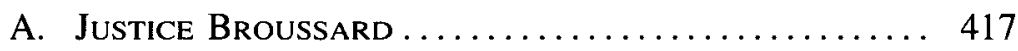

B. Justice MOSK ...................... 421

C. Justice Lucas ............................. 424

III. JUDICIAL TENURES $\ldots \ldots \ldots \ldots \ldots \ldots \ldots \ldots \ldots \ldots \ldots 426$

CONCLUSION: IMPOSSIBLE EVALUATIONS? .......... 429

\section{INTRODUCTION}

Are the decision-making methods of sitting judges susceptible to changes in their environment? California residents removed three of the seven justices of its Supreme Court in 1986 in a popular vote because they would not affirm death penalties. ${ }^{1}$ After the appointment of replacement justices, the court's approach to the death penalty changed dramatically. ${ }^{2}$ But three justices who sat in the court before the election remained on the court afterwards. They provide an interesting opportunity to study judicial behavior when a significant change in the composi-

† Professor of Law and John S. Grimes Fellow, Indiana University School of LawIndianapolis. I wish to thank a source who requests anonymity, Mark Ramseyer and the participants in the 1999 Olin Conference on the Economic Analysis of the Judiciary at Harvard Law School $f$ ir invaluable comments. This paper benefited greatly from the valiant assistance of Faith Long Knotts, Susan Butz, and the work of the editorial team of the Cornell Journal of Law and Public Policy.

1 This is, of course, an event of monumental significance in state law judicial history and in the operation of the California Constitution that is receiving increasing attention from commentators. See generally JosepH R. Grodin, In Pursuit of Justice; John H. Culver \& Chantel Boyens, Political Cycles of Life and Death: Capital Punishment As Public Policy in California, 65 AlB. L. Rev. 991 (2002); John H. Culver, The Transformation of the California Supreme Court: 1977-1997, 61 ALB. L. Rev. 1461 (1998); Robert S. Thompson, Judicial Retention Elections and Judicial Method: A Retrospective on the California Retention Election of 1986, 61 S. CAL. L. REv. 2007 (1988). For a more "macro" view of state courts, as they react to the polity's views about abortion, see generally Paul Brace et al., Judicial Choice and the Politics of Abortion: Institutions, Context, and the Autonomy of Courts, 62 AlB. L. Rev. 1265 (1999).

2 See infra Figure 1 and accompanying text. 
tion of a court occurs. While statistical studies of judicial decisions are legion, this author is aware of no case study that tracks the change of judicial voting and legal strategies surrounding a change of such magnitude. The votes of each regular justice on the California Supreme Court on cases involving the death penalty allow this study of changes in the attitudes of the justices who remained after the change in the court's composition. To avoid election-year interference and the disturbances that might exist immediately following a change in the court, this article studies judicial decision-making in 1984-1985 and 1989 cases where the Supreme Court of California reviewed lower court decisions imposing the death penalty. Three justices survived the 1986 election and were on the court at both times. Each of these justices changed their voting customs on death penalty cases.

Statistical analyses of judicial decisions forms so vast and growing a collection that a recent review took 17 pages to describe it. ${ }^{3}$ That evidence overwhelmingly shows that party affiliation of the appointing political figure-and, by extension, of the judge-influences judicial votes. That evidence, however, focuses largely on federal judges, the life tenure of which may influence the results. ${ }^{4}$ Other work has examined judicial citation practices. ${ }^{5}$ The incentives judges face have also been the object of scholarship. ${ }^{6}$ To reinforce the resulting presumption that judges are

3 Michael Heise, The Past, Present, and Future of Empirical Legal Scholarship: Judicial Decision Making and the New Empiricism, 2002 U. ILL. L. Rev. 819, 832-50 (2002).

4 See, e.g.. Frank B. Cross \& Emerson H. Tiller, Judicial Partisanship and Obedience to Legal Doctrine: Whistleblowing on the Federal Courts of Appeals, 107 YALE L.J. 2155 (1998); Richard L. Revesz, Congressional Influence on Judicial Behavior?: an Empirical Examination of Challenges to Agency Action in the D.C. Circuit, 76 N.Y.U. L. REv. 1100 (2001); Richard L. Revesz, Environmental Regulation, Ideology, and the D.C. Circuit, 83 VA. L. Rev. 1717 (1997); Richard L. Revesz, Litigation and Settlement in the Federal Appellate Courts: Impact of Panel Selection Procedures on Ideologically Divided Courts, 29 J. LEGAL STuD. 685 (2000).

5 The Chicago-Kent Law Review periodically holds symposia volumes on the citation patterns to law review articles and some contributions do compare judicial citation practices. See, e.g., Deborah J. Merritt \& Melanie Putnam, Judges and Scholars: Do Courts and Scholarly Journals Cite the Same Law Review Articles?, 71 CHI.-KENT. L. Rev. 871 (1996). Other works also study the citation practices of judges. See, e.g., Richard A. Posner, Cardozo: A Study in Reputation, 88-90 (1990); William M. LANDES et al., Judicial Influence: A Citation Analysis of Federal Courts of Appeals Judges, 27 J. LEGAL STuD. 271 (1998) (using the citations of published opinions of federal court of appeals judges to estimate the influence of individual judges); William H. Manz, Citations in Supreme Court Opinions and Briefs: A Comparative Study, 94 LAw LiBR. J. 267 (2002) (comparing the use of authority by the Supreme Court to the authorities cited in the briefs submitted to the Court); John H. Merryman, Toward a Theory of Citations: an Empirical Study of the Citation Practice of the California Supreme Court in 1950, 1960, and 1970, 50 S. CAL. L. REv. 381, 414-22 (1977); Richard A. Posner, The Learned Hand Biography and the Question of Judicial Greatness, 104 YALE L.J. $511,534-40$ (1994) (studying the citations of Learned Hand).

6 See, e.g., Richard A. Posner, Overcoming Law 109-44 (1996) (with further citations); Stephen M. Bainbridge \& G. Mitu Gulati, How Do Judges Maximize? (The Same Way Everybody Else Does - Boundedly): Rules of Thumb in Securities Fraud Opinions, 51 EMORY 
unlikely to disregard incentives, the evidence also shows retaliation against judges by the executive power. ${ }^{7}$ Sitting judges have bitterly disputed the statistics questioning the impartiality of judges. ${ }^{8}$ Because this evidence comes predominantly from life-tenured judges, the question of how elected judges react to the threat of retaliation by a state electorate remains unanswered. The 1986 California elections offer the opportunity to observe the response of judges to a clear change. This article studies voting in two periods: before and after the elections. The background issue can be framed as one of consistency: Is each judge's voting pattern consistent between the two periods?

This article's review of judicial voting practices reveals three inconsistencies which relate to personal preferences, the law, and political party affiliation. Voting patterns are inconsistent with personal preferences because the patterns change. ${ }^{9}$ They are inconsistent with the law because their change does not match the change of the law. ${ }^{10}$ They are inconsistent with political party affiliation because they change when the parties' positions do not. ${ }^{11}$ The votes are a small component of larger, more complex judicial strategies.

Because this article is a case study rather than a statistical analysis of a large sample, it allows a detailed look at the likely strategies underlying each justice's votes. The inconsistency with an explanation based on political affiliation shows that statistical validations of strategic voting, while possible, are unlikely. Therefore, statistical tests will tend to fail to find evidence of strategic voting.

L.J. 83 (2002) (studying the use of heuristics in securities law opinions); Nicholas L. Georgakopoulos, Discretion in the Career and Recognition Judiciary, 7 U. CHI. L. ScH. RoundTABLE 205 (2000) (comparing the judicial incentives produced by the civil law model of career judges to the common law system where judgeships recognize and reward a complete previous legal career).

7 See J. Mark Ramseyer \& Eric B. Rasmusen, Judicial Independence in a Civil Law Regime: The Evidence from Japan, 3 J. L. Econ. \& ORG. 259 (1997) (studying executive influence over the Japanese judiciary); J. Mark Ramseyer and Eric B. Rasmusen, Why is the Japanese Conviction Rate so High?, 30 J. Legal Stud. 53 (2001); see also J. Mark Ramseyer, The Puzzling (In)Dependence of Courts: A Comparative Approach, 23 J. LEGAL STUD. 721 (1994).

8 See, e.g., Harry T. Edwards, Collegiality and Decision Making on the D.C. Circuit, 84 VA. L. REv. 1335 (1998) (discussing the role of judicial collegiality in decision making); Patricia M. Wald, A Response to Tiller and Cross, 99 CoLum. L. Rev. 235 (1999) (questioning a proposal to appoint judges based on the President's political affiliation); Patricia M. Wald, Some Real-Life Observations About Judging, 26 IND. L. Rev. 173, 179-82 (1992).

9 See text accompanying note 48 for Justice Broussard. For Justice Lucas, see text accompanying notes 83-97.

10 The leading example is Justice Mosk, who cast a smaller proportion of votes to affirm the imposition of the death penalty after the elections. Justice Lucas' last ten affirming votes in 1985 ignored precedent, see infra text accompanying note 91.

11 See infra, text accompanying note 52. 
The circumstances of the 1986 elections are unusual. The $1986 \mathrm{Cal}-$ ifornia elections were a crucial development in the possibility of the United States curtailing the use of the death penalty. Not only were these elections an extraordinary event for death penalty jurisprudence, they were also a demonstration of an unusual institutional practice-the removal of sitting justices in direct, judicial elections. A study of an exercise of the electorate's power through the unusual institution of judicial elections would be remiss not to attempt to assist their evaluation as an institution in the context of modern democratic systems.

California Supreme Court decisions in the years since the 1986 election allow the examination of the tenures of the justices appointed in the shadow of the 1986 elections, which were unusually short. ${ }^{12}$ This is a potentially crucial secondary effect of the conflict over the death penalty and the method by which it was resolved.

Part I describes briefly the events in California leading up to the 1986 judicial elections and the sample for this case study. Part II applies statistical tests. Part III compares judicial tenures before and after the death-penalty conflict.

\section{THE BACKDROP FOR THE CALIFORNIA JUDICIAL ELECTIONS OF 1986}

Justices of the California Supreme Court are subject to unopposed retention elections. ${ }^{13}$ Retention elections are the product of a conservative movement at the first part of the twentieth century that feared populism. ${ }^{14}$ These elections were designed to remove the base side of politics from the process of electing the judiciary. Ironically, conservative forces had to overcome the pro-incumbent bias of retention elections in 1986 to remove, for the first and only time in California history, ${ }^{15}$ three justices who were considered "soft" on crime. The Supreme Court was accused of countering the electorate's desire for the imposition of the death penalty that had been expressed in repeatedly successful referenda. ${ }^{16}$

The electoral cycle of California Justices is unusual. Nominally, the term of California justices is 12 years, but beginning the 12-year cycle may require up to two elections. Immediately after the justice's appointment by the Governor, the justice must stand for election at the next general election. Upon winning that election, the justice steps into the predecessor's 12-year cycle, so that if the predecessor would have been

12 See infra text accompanying notes 100-101.

13 Cal. Const. art. VI, $\$ 16$.

14 Grodin, supra note 1, at 164-66 (discussing how California adopted the retention election system in 1934).

15 Id. at 166 (noting that no justice has been removed since then either).

16 See infra text accompanying notes 21 and 22. 
up for reelection in less than 12 years, the newly appointed, and elected, justice must stand for re-election at that time as well. ${ }^{17}$ While the maximum of two elections may be necessary before a justice is into the twelve-year cycle, if the justice's appointment occurs immediately before the predecessor would have been up for reelection, that single vote will approve the appointment and start the twelve year cycle. Thereafter, the previous justice's 12-year cycle continues. Accordingly, not all judges are up for re-election at every general election, neither is the number of justices that will be up for election fixed, but rather it depends on recent appointments.

Death penalty law has attracted voluminous commentary. Briefly, in 1972 the California Supreme Court held that the death penalty violated the California Constitution's "cruel and unusual punishment" clause in People v. Anderson, ${ }^{18}$ which was overruled by initiative in the next election. ${ }^{19}$ That same year, the United States Supreme Court held unconstitutional all existing death penalty statutes. ${ }^{20}$ A narrow and fractured majority objected to the unguided discretion of juries in imposing the death penalty. Furman inflamed the public opinion. The approval of capital punishment, which in polls was at $50 \%$ in the summer of 1972 , jumped to $57 \%$, and within a year nineteen states had passed new death penalty statutes, soon to be followed by sixteen more states. ${ }^{21}$ The reaction of the California polity included two statutory schemes and two popular votes-Proposition 17 in the 1972 elections restoring the constitutionality of the death penalty and the "Briggs" initiative in 1978 which produced a stricter capital punishment regime than the legislative proposition. ${ }^{22}$ The United States Supreme Court approved the death penalty statutes that sought to guide juror discretion in Gregg v. Georgia, ${ }^{23}$

17 CAL. Const. art. VI, $\S 16(a)$ ("IT]erms are 12 years beginning the Monday after January 1 following their election, except that a judge elected to an unexpired term serves the remainder of the term.").

18493 P.2d 880 (Cal. 1972).

19 Proposition 17, amending Article I, $\$ 27$, reads:

The death penalty provided for under [existing death-penalty] statutes shall not be deemed to be, or to constitute, the infliction of cruel or unusual punishments within the meaning of Article 1, Section 6 nor shall such punishment for such offenses be deemed to contravene any other provision of this constitution.

Proposed Amendments to Constitution, Propositions and Proposed Laws, General Election, Nov. 7, 1972, Part II - app. at 21.

20 Furman v. Georgia, 408 U.S. 238 (1972).

21 Edward lazarus, Closed Chambers: The First Eyewitness Account of the Epic Struggles Inside the Supreme Court 111 (1999).

22 See Steven F. Shatz \& Nina Rivkind, The California Death Penalty Scheme: Requiem for Furman?, 72 N.Y.U. L. REv. 1283, 1307-10 (1997).

23428 U.S. 153 (1976). 
and eventually also approved aspects of California's scheme in Tuilaepa v. California. ${ }^{24}$

The principal target of the popular movement favoring death penalties was Chief Justice Rose E. Bird. In the 1978 elections she was confirmed with a bare majority, under $52 \%$, the narrowest majority on record at that time. ${ }^{25}$ These same elections produced the "Briggs" death penalty initiative. ${ }^{26}$ In 1986 the electorate removed Justice Bird along with Justices Joseph R. Grodin and Cruz Reynoso, apparently because of their leniency on crime.

California death penalty appeals have an attractive feature for their quantitative study. Settlements and non-prosecutions terminate ordinary disputes without a court opinion. The study of court opinions about such disputes is hampered by "selection bias," the phenomenon that the observed opinions are missing the disputes that were settled or dropped.

24512 U.S. 967 (1994).

25 Grodin, supra note 1 , at 168 .

26 The "Briggs death penalty initiative" took effect the day after the elections of November 7, 1978. See, e.g., People v. Murtishaw, 48 Cal. 3d 1001, 1025 (1989). It amended Cal. Penal Code $\S 190.2$ to define the special circumstances of murder that cause it to be punishable by life imprisonment without parole or by death. Section 190.2 read as follows until 1989:

(a) The penalty for a defendant found guilty of murder in the first degree shall be death or confinement in state prison for a term of life without the possibility of parole in any case in which one or more the following special circumstances has been charged and specially found ... to be true:

(1) The murder was intentional and carried out for financial gain.

(2) The defendant was previously convicted of murder in the first or second degree. ...

(3) The defendant has, in this proceeding, has been convicted of more than one offense of murder in the first or second degree. . . .

(14) The murder was especially heinous, atrocious, or cruel, manifesting exceptional depravity....

(15) The defendant intentionally killed the victim while lying in wait.

(16) The victim was intentionally killed because of his or her race, color, religion, nationality, or country of origin.

(17) The murder was committed while the defendant was engaged in, or was an accomplice in, the commission of, attempted commission of, immediate flight after committing, or attempting to commit, the following felonies: (i) Robbery . . .; (ii) Kidnapping . . .; (iii) Rape . . .; (vii) Burglary . . .; (viii) Arson . . .; (x) Mayhem ....

(18) The murder was intentional and involved the infliction of torture. . .

(b) Every person ... . intentionally aiding, abetting, ... or assisting any actor in the commission of murder in the first degree shall suffer death or confinement in state prison for a term of life without the possibility of parole, in any case in which one or more of the special circumstances [are found true]. . . .

Id. The text the Briggs initiative replaced was more narrow. 
Selection bias confounds the quantitative analysis of court opinions. ${ }^{27}$ California death penalty appeals are free from selection bias because the California Supreme Court automatically reviews every imposition of the death penalty. Indeed, this sample of opinions includes reviews of trials of defendants who seek the death penalty. ${ }^{28}$

An issue that must precede this analysis regards the confidence in a statistical study of justices' votes regarding the propriety of imposing the death penalty. One might be concerned that features of the crime may influence courts and therefore the observed changes of judges' votes may have other causes, such as a changed crime rate. California appellate courts, as do most American appellate courts, review the application of the legal, rather than factual, conclusions of the trial court. ${ }^{29}$ Whereas

27 The accumulating research on selection bias in judicial opinions has the "Priest/Klein hypothesis" as its milestone. Professors Priest and Klein hypothesized that the effect of settlements would be symmetrical, so that the observed "win rate" would tend to be $50 \%$. Subsequent research has found deviations from the predicted $50 \%$ win rate. See generally George Priest \& Benjamin Klein, The Selection of Disputes for Litigation, 13 J. LEGAL STUD. 1 (1984). Others, however, have observed deviations from the hypothesis. See, e.g., Leandra Lederman, Which Cases Go to Trial?: An Empirical Study of Predictors of Failure to Settle, 49 CASE W. RES. L. Rev. 315 (1999) (finding biases in tax litigation and settlements); Peter Siegelman \& Joel Waldfogel, Toward a Taxonomy of Disputes: New Evidence Through the Prism of the Priest/Klein Model, 28 J. Legal Stud. 101, 130 (1999) (studying over 20,000 cases; "document[ing] that litigation outcomes (adjudication and plaintiff win rates) vary substantially across case types"); Peter Siegelman \& John J. Donohue III, The Selection of Employment Discrimination Disputes for Litigation: Using Business Cycle Effects to Test the Priest-Klein Hypothesis, 24 J. LEGAL STUD. 427 (1995) (finding and predicting sensitivity of employment litigation to the business cycle); Samuel R. Gross \& Kent D. Syverud, Getting to No: A Study of Settlement Negotiations and the Selection of Cases for Trial, 90 MiCH. L. Rev. 319 (1991) (studying 529 jury trials and the corresponding settlement negotiations, finding that the PriestKlein hypothesis is "inconsistent with actual settlement negotiations and trial outcomes"); Gregory Todd Jones, Note, Testing for Structural Change in Legal Doctrine: An Empirical Look At the Plaintiff's Decision to Litigate Employment Disputes Decade After the Civil Rights Act of 1991, 18 GA. ST. U. L. Rev. 997 (2002) (confirming the predictions of Donohue \& Siegelman); $c f$ Daniel Kessler et al., Explaining Deviations from the Fifty-Percent Rule: $A$ Multimodal Approach to the Selection of Cases for Litigation, 25 J. LEGAL STUD. 233 (1996) (attempting to reconcile the observed deviations from the $50 \%$ win rate with the Priest-Klein hypothesis).

28 People v. Massie, 40 Cal. 3d 620 (1985) (ruling that the acceptance of a guilty plea in capital case is improper, even with consent of counsel); see also People v. Chadd, 28 Cal. $3 \mathrm{~d}$ 739 (1981) (ruling that the acceptance of guilty plea in capital case is improper without agreement of counsel).

29 People v. Nicolaus, 817 P.2d 893, 905-06, reh'g denied 1991 Cal LEXIS 5622, stay granted 1992 Cal LEXIS 682, cert. denied 505 U.S. 1224 (1992) (refusing to review the sufficiency of the evidence for proof beyond reasonable doubt and limiting review to the existence of evidence, noting that "[t]he relevant inquiry on appeal is whether "any rational trier of fact' could have been ... persuaded [beyond reasonable doubt]") quoting People v. Lucero, 44 Cal. 3d 1006, 1020 (1988), (emphasis in original); Crocker Nat'l Bank v. City \& County of San Francisco, 782 P.2d 278, 281 (1989) ("If the pertinent inquiry requires application of experience with human affairs, the question is predominantly factual and its determination is reviewed under the substantial-evidence test. If, by contrast, the inquiry requires a critical consideration, in a factual context, of legal principles and their underlying values, the question 
the nature of the crimes committed by defendants or public sentiment may arguably influence the findings of a trial court, those findings of fact are reviewed by an appellate court, minimizing the potential for extraneous influences. Events such as crime waves or a crack epidemic might influence triers of fact, for example. The result may be that the burden of proof for conviction on given evidence appears easier to meet. Appellate review of the convictions, however, would not review such conclusions. ${ }^{30}$ Thus, it is reasonable to start from the hypothesis that the rate of affirming death penalties does not depend on socioeconomic circumstances.

The sample consists of the opinions of the California Supreme Court that review the imposition of the death penalty in 1984, 1985, 1989 , and 1990. These years are sufficiently far removed from the election so as not to be disrupted by transitional effects. They were collected from LEXIS by searching in the database of California opinions for opinions of the Supreme Court during those years that mention "death penalty." 31 Their thrust is captured in the following figure.

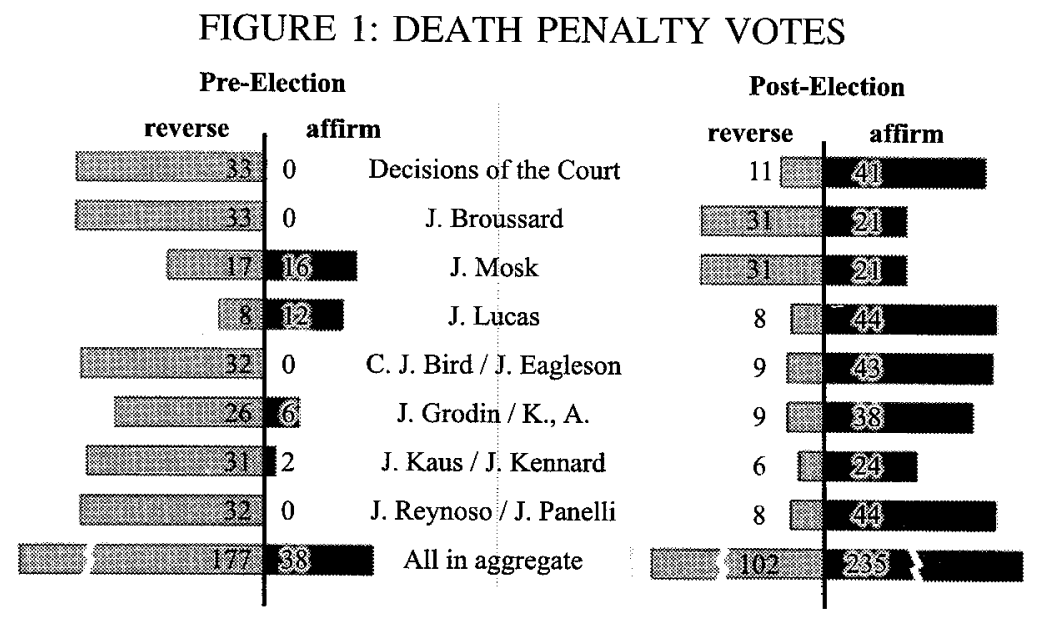

This table compares the death penalty decisions from 1984-85 to those from 1989-90. The two time periods form two panels, one on each side of the names of the judges. The reversing and affirming votes of each period form a bar graph. The gray bars that extend to the left correspond to reversal votes and the black bars that extend to the right to affirming votes. The first row corresponds to the entire court and is labeled "Decisions of the Court." It reviewed 33 death penalty cases from

is predominantly legal and its determination is reviewed independently."). See also Appellate Review, 5 Aм. Jur. 2d $\$ 695$ et seq. (2003).

$30 \mathrm{Id}$.

31 The "command search" used is "states; cacts; 'death penalty' and court(supreme) and date $=19$ 
1984-85 and 52 from 1989-90. The next seven rows correspond to each justice. The three justices on the court during both periods occupy the first three rows (Broussard, Mosk, and Lucas, in the order they are discussed below). The next four rows hold the votes of different justices in the two periods. A slash separates the pre-election justice from the postelection justice of the same row. For example, the row "C.J. Bird / J. Eagleson" holds the voting record of Chief Justice Rose Bird during 1984-85 and that of Justice Eagleson during 1989.32 The last row, labeled "All in aggregate", holds the aggregation of the individual justices' votes. The chief justice during $1989-90$ is Lucas. The regular justices' votes aggregate to 337 .

The pre-election sample from 1984 and 1985 reveals a court that is reluctant to impose the death penalty. The 33 opinions of the sample consist of 10 death penalty cases from $1984^{33}$ and 23 from $1985 .{ }^{34}$ Of these, none affirm the penalty. The seven regular justices in 1984-1985 are Bird, Broussard, Grodin, Kaus, Lucas, Mosk, and Reynoso. In aggregate, 215 votes were cast by the regular justices in 1984-1985..$^{35}$ Bird, Broussard and Reynoso never vote to affirm a death penalty. Kaus casts

32 The table fails to indicate two changes in each period. Justice Kaufman left the Court during 1990 and Justice Arabian was appointed to the Court that year. Their voting record is in the fourth row, marked "Pre: Grodin; Post: K., A."

33 The search finds 15 cases from 1984, of which 5 drop out because they do not involve review of the imposition of the death penalty. Included in the 1984 sample are People v. Bigelow, 37 Cal. 3d 731 (1984); People v. Armendariz, 37 Cal. 3d 573 (1984); People v. Holt, 37 Cal. 3d 436 (1984); People v. Turner, 37 Cal. 3d 302 (1984); People v. Ramos, 37 Cal. 3d 136 (1984); People v. Whitt, 36 Cal. 3d 724 (1984); People v. Alcala, 36 Cal. 3d 604 (1984); People v. Garcia, 36 Cal. 3d 539 (1984); People v. Lanphear, 36 Cal. 3d 163 (1984); and People v. Harris, 36 Cal. 3d 36 (1984). Excluded from the 1984 sample are Williams v. Superior Ct., 36 Cal. 3d 441 (1984); Corenevsky v. Superior Ct., 36 Cal. 3d 307 (1984); People v. Zimmerman, 36 Cal. 3d 154 (1984); People v. March, 36 Cal. 3d 134 (1984); and People v. Burroughs, 35 Cal. 3d 824 (1984).

34 The search returned 29 cases from 1985, of which 6 are not relevant because the court does not review the imposition of the death penalty. Included in the 1985 sample are People $v$. Memro, 38 Cal. 3d 658 (1985); People v. Frank, 38 Cal. 3d 711 (1985); People v. Boyd, 38 Cal. 3d 762 (1985); People v. Hayes, 38 Cal. 3d 780 (1985); People v. Anderson, 38 Cal. 3d 58 (1985); People v. Croy, 41 Cal. 3d 1 (1985); People v. Phillips, 41 Cal. 3d 29 (1985); People v. Leach, 41 Cal. 3d 92 (1985); People v. Walker, 41 Cal. 3d 116 (1985); People v. Balderas, 41 Cal. 3d 144 (1985); People v. Hamilton, 41 Cal. 3d 211 (1985); People v. Davenport, 41 Cal. 3d 247 (1985); People v. Silbertson, 41 Cal. 3d 296 (1985); People v. Lucky, 41 Cal. 3d 315 (1985); People v. Deere, 41 Cal. 3d 353 (1985); People v. Hamilton, 41 Cal. 3d 408 (1985); People v. Massie, 40 Cal. 3d 620 (1985); People v. Fuentes, 40 Cal. 3d 629 (1985); People v. Brown, 40 Cal. 3d 512 (1985); People v. Guerra, 40 Cal. 3d 377 (1985); People v. Montiel, 39 Cal. 3d 910 (1985); People v. Frierson, 39 Cal. 3d 803 (1985); and People v. Chavez, 39 Cal. 3d 823 (1985). Excluded from the 1985 sample are Pollack v. DMV, 38 Cal. 3d 367 (1985); People v. Coleman, 38 Cal. $3 d 69$ (1985); People v. Fritz, 40 Cal. 3d 227 (1985); Green v. Superior Ct., 40 Cal. 3d 126 (1985); People v. Weidert, 39 Cal. 3d 836 (1985); and People v. Trevino, 39 Cal. 3d 667 (1985).

35 Justices Broussard, Kaus, and Mosk voted on all 33 cases. Reynoso, Grodin and Bird each did not vote on one case. Lucas, who was appointed in 1984, voted on 20. 
two affirming votes out of 33 for a $6 \%$ ratio of affirming votes. ${ }^{36}$ Grodin casts six affirming votes, or $18 \%$. Mosk casts 16 affirming votes, or $48 \%$. Lucas, who is appointed in 1984 , casts 14 affirming votes out of 20 , or $70 \%$.

The opinions after the elections present a very different image. The 52 opinions of the post-election sample consist of 26 death penalty cases from $1989^{37}$ and 26 from 1990.38 Of the 52 cases in 1989-90 the death penalty is affirmed in 41 , or $79 \%$. To the extent that the electorate intended to produce a court that would uphold the death penalty often, it succeeded. The electorate managed to increase death penalty affirmances from 0 to $79 \%$.

The post-election sample also has more death penalty opinions. Did the elections also lead to this result? A superficial statistical analysis

36 The only votes by Kaus affirming the death penalty in the sample are in People v. Harris, 36 Cal. 3d 36 (1984); and People v. Frank, 38 Cal. 3d 711 (1985). Kaus was in the minority in these cases, and Lucas had not yet joined the court.

37 The same search as in note 31 above, with the necessary date adjustment, was used. The search finds 27 cases from 1989, of which one drops out because it does not involve review of the imposition of the death penalty. Included in the 1989 sample are People $v$. Jackson, 49 Cal. 3d 1170 (1989); People v. Hunter, 49 Cal. 3d 957 (1989); People v. Lang, 49 Cal. 3d 991 (1989); People v. Bell, 49 Cal. 3d 502 (1989); People v. Carrera, 49 Cal.3d 291 (1989); People v. Andrews, 49 Cal. 3d 200 (1989); People v. Hamilton, 48 Cal. 3d 1142 (1989); People v. Bloom, 48 Cal. 3d 1194 (1989); People v. Bittaker, 48 Cal. 3d 1046 (1989); People v. Williams, 48 Cal. 3d 1112 (1989); People v. Murtisaw, 48 Cal. 3d 1001 (1989); People v. Sheldon, 48 Cal. 3d 935 (1989); People v. Allison, $48 \mathrm{Cal}$. 3d 879 (1989); People v. Burton, 48 Cal. 3d 843 (1989); People v. Bonillas, 48 Cal. 3d 757 (1989); People v. Morales, 48 Cal. 3d 527 (1989); People v. Boyer, 48 Cal. 3d 247 (1989); People v. Coleman, 48 Cal. 3d 112 (1989); People v. Wright, 48 Cal. 3d 168 (1989); People v. Johnson, 47 Cal. 3d 1194 (1989); People v. Robertson, 48 Cal. 3d 18 (1989); People v. Harris, 47 Cal. 3d 1047 (1989); People v. Edelbacher, 47 Cal. 3d 983 (1989); People v. Farmer, 47 Cal. 3d 888 (1989); People v. Bonin, 47 Cal. 3d 808 (1989); and People v. Garrison, 47 Cal. 3d 746 (1989). The sample from 1989 excludes Frank v. Superior Ct., 48 Cal. 3d 632 (1989).

38 The same search as in note 31 above, with the necessary date adjustment, was used. The search returned results for 30 cases from 1990, of which four are irrelevant because the court did not review the imposition of the death penalty. Included in the 1990 sample are People v. Kaurish, 52 Cal. 3d 648 (1990); People v. Hayes, 52 Cal. 3d 577 (1990); People v. Benson, 52 Cal. 3d 754 (1990); People v. Taylor, 52 Cal. 3d 719 (1990); People v. Anderson, 52 Cal. 3d 453 (1990); People v. Wright, 52 Cal. 3d 367 (1990); People v. Gallego, 52 Cal. 3d 115 (1990); People v. Haskett, 52 Cal. 3d 210 (1990); People v. Gonzalez, 51 Cal. 3d 1179 (1990); People v. Kelly, 51 Cal. 3d 931 (1990); People v. Medina, 51 Cal. 3d 870 (1990); People v. Frank, 51 Cal. 3d 718 (1990); People v. Whitt, 5l Cal. 3d 620 (1990); People v. Sanders, 51 Cal. 3d 471 (1990); People v. Stankewitz, 51 Cal. 3d 72 (1990); People v. Gordon, 50 Cal. 3d 1223 (1990); People v. Ramirez, 50 Cal. 3d 1158 (1990); People v. Holloway, 50 Cal. 3d 1098 (1990); People v. Miller, 50 Cal. 3d 954 (1990); People v. Marshall, 50 Cal. 3d 907 (1990); People v. Mattson, 50 Cal. 3d 826 (1990); People v. Turner, 50 Cal. 3d 668 (1990); People v. Clark, 50 Cal. 3d 583 (1990); People v. Douglas, 50 Cal. 3d 468 (1990); People v. Lewis, 50 Cal. 3d 262 (1990); and People v. Thompson, 50 Cal. 3d 134 (1990). The sample from 1990 excludes Raven v. Deukmejian, 52 Cal. 3d 336 (1990); Curl v. Superior Court, 51 Cal. 3d 1292 (1990); In re Fields, 51 Cal. 3d 1063 (1990); and Gadda v. State Bar of California, 50 Cal. 3d 344 (1990). 
answers this question in the affirmative. Closer investigation reveals a richer picture.

Each year, the court issues a number of death penalty opinions. If after the elections the court tends to issue more opinions, the statistical support for change would be a rejection of the hypothesis that the court tends to issue the same number of opinions. The corresponding statistical test is the t-test and using it to compare 1980-86 to 1987-2003 produces significant results. The t-test indicates that, if the court's tendency had not changed, the observed difference would occur by chance with a probability of $1.3 \%$. In terms of "statistical confidence" this means a $98.7 \%$ confidence that the post-election court's tendency increased to issue more opinions. ${ }^{39}$

As we will see again, the statistical conclusion turns out to be facile. A picture is worth a thousand words, and a graph is worth more than one statistical test. The statistical test ignores the richness that may be immediately apparent in a graph of the data. The following table shows the number of the California Supreme Court opinions regarding the death penalty in the years from 1980 to $2003 . .^{40}$

\section{FIGURE 2: THE NUMBER OF DEATH PENALTY OPINIONS,} 1980-2003

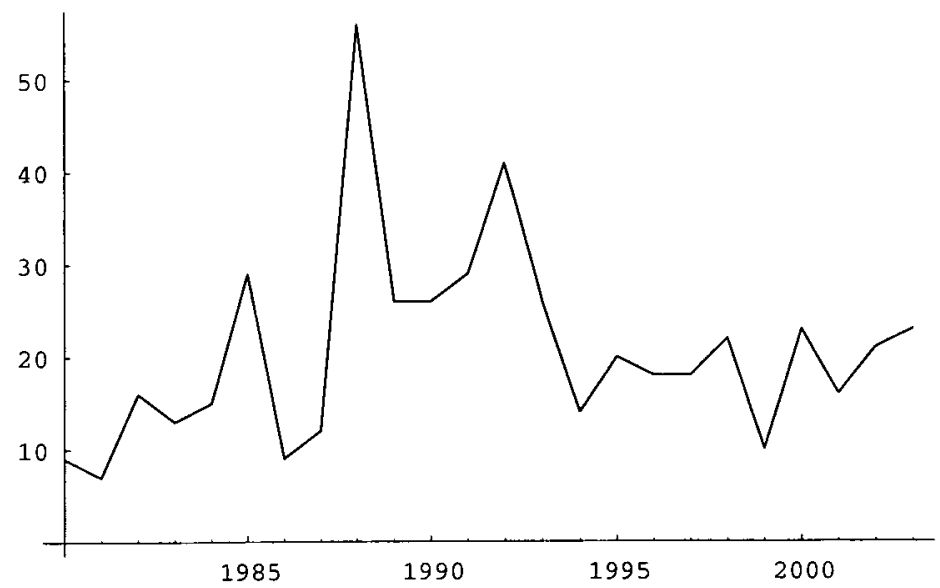

39 From 1980 to 1986 the court issued, on average, 14 death penalty opinions per year, with a standard deviation of 7.42 and a count of 7 years. From 1987 to 2003 , the court averaged 23.6 death penalty opinions per year, with a standard deviation of 12.3 and a count of 12 years. Books on introductory statistics discuss the "t-test." See, e.g., David Freedman ET al., Statistics 490-95 (3rd ed. 1998).

40 The searches were the same as described in note 31 , above, with some opinions excluded for each year's search because they did not review the death penalty. The data underlying the table are '80: 9 opinions; ' $81: 7$ ops.; '82: 16 ops.; '83: 13 ops.; '84: 15 ops.; '85: 29 ops.; ‘86: 9 ops.; '87: 12 ops.; '88: 56 ops.; '89: 26 ops.; ‘90: 26 ops.; ‘91: 29 ops.; ‘92: 41 ops.; ‘93: 26 ops.; ‘94: 14 ops.; '95: 20 ops.; ‘96: 18 ops.; ‘97: 18 ops.; ‘98: 22 ops.; ‘99: 10 ops.; '00: 23 ops.; '01: 16 ops.; '02: 21 ops.; '03: 23 ops. 
Would one conclude from this graph that the post-election court issued death penalty opinions at a faster rate? An affirmative answer to that question would require a graph of two constant states. The pre-election court would tend to produce opinions close to one number; the postelection court would tend to produce them close to a greater number. Rather than two constant states, the graph suggests an increasing trend before elections and a steady state after 1992. The years from 1987 to 1992 are different; they can fit into several theories.

The appearance of an increasing trend before the elections is not surprising. After the death penalty was reinstated in $1978,{ }^{41}$ not all cases reached the California Supreme Court with the same speed. Even if the same number of capital sentences were imposed every year, only the exceptionally fast ones would reach the Supreme Court within one year. The number of opinions during an initial, transitional period would be increasing. This does not explain, however, the number of opinions from 1987 to 1992 . If the post-election court reviewed more capital sentences, one would expect a permanent increase, but the apparent constancy of the number of opinions after 1992 contradicts that hypothesis. The puzzles remain.

A closer look at the opinions, beyond the raw statistical data, reveals the answer. Justice Lucas reported that 170 death penalty appeals were pending before the California Supreme Court in late 1985.42 The post-election court seemed to consider the cure of this particular backlog more approachable than the pre-election court did. Dealing with a backlog suggests increased production of opinions for a few years. After the backlog was cleared, the California Supreme Court returned to a normal number of opinions. After all, the supreme court can review only the number of death penalties imposed by the trial courts.

Allen E. Broussard, Stanley Mosk and Malcolm M. Lucas are the justices who were on the California Supreme Court both before and after the 1986 election. The first issue is whether their voting records in 198990 were consistent with their voting records in 1984-85. The next section examines the three justices in turn.

\section{CONSISTENCY BETWEEN 1984 AND 1989}

After the 1986 election, the court followed a vastly different voting pattern. This is not at all surprising. What changes should be expected from the Justices who did remain on the court? Since they were the same individuals, one could expect them to exhibit some consistency. Should

41 See Schatz \& Rivkind, supra note 22 and accompanying text.

42 People v. Brown, 40 Cal. 3d 512, 546-47 (1985) (Lucas, J., concurring and dissenting). 
a justice who was always satisfied with the procedure followed in death penalty trials in 1984-85, find errors in 1989? Could a justice who never found the trial procedure adequate in 1984-85, be expected to approve the procedure of over a fifth of the cases in 1989? Yet, both phenomena appear.

Each one of the voting records of the three justices justifies a closer look by revealing texture that a simple count hides. The exposition will start with the only judge that changed his votes in the same direction as the court, Justice Broussard. We will proceed to the judge who appeared most responsive to the electorate's incentives, Justice Mosk, and will finally examine the attitudes of Justice Lucas, who was the Chief Justice of the California Supreme Court in 1989.

\section{A. Justice Broussard}

Justice Broussard voted with the court during the 1984-85 session. During that period, the California Supreme Court never affirmed a death penalty and neither did Broussard. When circumstances changed, Broussard also changed his standard, though not enough to match the new court. In 1989-90, the court affirmed $79 \%$ of the death penalty convictions it reviewed, while Justice Broussard voted to affirm only about $40 \%$ of the capital sentences.

A different way to quantify Justice Broussard's attitudes in death penalty reviews is to ask how often he agreed with the court. In 1984-85, he agreed with the court in all of the cases. By contrast, in 1989-90, Justice Broussard disagreed in twenty cases, or $38 \%$ of the time. Not surprisingly, Justice Broussard never voted to affirm a death penalty sentence in the eleven cases where the court reversed the sentence. Nevertheless, Broussard did vote with the post-election Court to affirm twentyone death sentences, which is puzzling. His re-election was not approaching (he would have been up for re-election in 1994 but retired prior to that). He never wrote a separate concurring opinion to affirm a death sentence. In four cases, Justice Broussard joined a concurring opinion to affirm of Justice Mosk, in which a more lenient stance than that of the court was articulated. ${ }^{43}$ Cleary, Justice Broussard did not agree with the post-election Court's attitudes. Still, his dissents were very civil and nonconfrontational.

In one example, the majority found that not instructing the jury on a lesser but likelier offense of theft, rather than burglary, did not harm the defendant. Justice Broussard's dissent argued that theft was the more likely offense and that its absence led the jury to convict the defendent of

43 People v. Anderson, 52 Cal. 3d 453, 485-86 (1990); People v. Kelly, 51 Cal. 3d 931, 972-74 (1990); People v. Douglas, 50 Cal. 3d 468, $541-42$ (1990); People v. Jackson, 49 Cal. 3d 1170, 1209-11 (1989). 
the more serious charge of burglary, which unlike theft, was an offense that could lead to the death penalty. ${ }^{44}$ Justice Broussard's sharpest prose was limited to pointing out a contradiction in the majority's argument that the jury's finding of burglary cured the error:

It is simply not logical to use the products of the error to dispel the prejudice arising from the error, as the majority does. ${ }^{45}$

The identification of contradictions in criminal procedure does not lend itself to gripping rhetoric. Examples of Justice Broussard's aggressive stances tend to be complex. Their strength lies in logic, rather than brevity:

The majority, however, declare that even though the state is withholding potentially exculpatory evidence, the limited scope and pleading requirements of habeas corpus prevent defendant from ... discovering the concealed evidence .... [I]t seems appropriate to quote a court with a different perspective on the scope of habeas corpus: "The writ of habeas corpus is the fundamental instrument for safeguarding individual freedom against arbitrary and lawless state action . . .."46

Whereas someone without Justice Broussard's demeanor would have used the last quote from the United States Supreme Court to drive home his point, Justice Broussard let understatement carry his message. The reader initially senses a pointless comparison, that a different court holds the differing view that habeas corpus protects defendants against lawless states. Closer inspection reveals that the different court happens to be the United States Supreme Court. The reader does not hear from Justice Broussard that California's enforcement authorities have crossed the boundary of lawlessness and that its Supreme Court denies defendants protections that they would receive in federal courts.

Justice Broussard's refusal to take a confrontational stance either in his votes or his text is remarkable. Such civility certainly corresponds to the ideal of the dispassionate judge. A focus on incentives, however, would require an inquiry into whether accommodating the majority produces a benefit. Going along with the majority creates good will that Broussard could use in other instances, or, by agreeing with the majority, he could influence the writing of the majority opinion so that it might take a more lenient tone than if he had stayed in the minority. Indeed, he

44 People v. Turner, 50 Cal. 3d 668, 721-26 (1990).

45 Id. at 726.

46 People v. Gonzalez, 51 Cal. 3d 1179, 1290 (1990) (quoting Harris v. Nelson, 394 U.S. $286,290-92(1969))$. 
does write one affirming opinion for the majority in a case where Justice Mosk, who usually joins Justice Broussard in dissent, dissents alone. ${ }^{47}$

Compared to the voting records of Justices Mosk and Lucas, Broussard's record is the one most amenable to statistical analysis. Such analysis suggests that Justice Broussard's voting cannot be reconciled with individual consistency, commitment to his political party, or changes in the law.

The voting patterns of Justice Broussard do not exhibit any individual consistency. Justice Broussard would be consistent if his voting did not change over time. Given that his voting did change, he would be consistent only if this change could be explained by chance. The statistical method known as $\chi^{2}$-test calculates that probability, which in this case is minimal. 48

The scholarly analysis of judicial voting focuses on the role of political parties in judicial voting patterns. ${ }^{49}$ As Justice Broussard's voting record clearly places him on the left end of the ideological spectrum, the issue is to examine how the position of the left-leaning Democratic party on the death penalty changed from 1985 to 1989 . The change is undeniable, exemplified in the passage of the Federal Death Penalty Act of $1994^{50}$ under Democratic leadership. ${ }^{51}$ Assuming that the Democratic party ceased to oppose the death penalty, a hypothesis can be formed about why Justice Broussard could be expected to change his voting. If by joining the majority Justice Broussard could obtain a benefit, either in the form of good-will or in the form of authoring a less severe opinion, then the testable hypothesis becomes whether Justice Broussard votes with the court. However, Justice Broussard often dissented, and his votes differed significantly from those of either the court or the other justices. ${ }^{52}$ He did not follow the court, despite the fact that he did so more than if he had maintained his pre-election stance of never affirming a death penalty.

47 People v. Ramirez, 50 Cal. 3d 1158 (1990).

48 Applying the test to compare Justice Broussard's votes either before or after the election produces a probability of $0.5 \%$. The $\chi^{2}$-test is explained in DAVID FREEDMAN ET AL., Statistics $537-40$ (3rd ed. 1998) (using as an example the probability that men may have a greater tendency to be left-handed).

49 See supra notes 3-8.

so This statute was enacted as an internal part of the Violent Crime Control and Law Enforcement Act of 1994, Pub. L. No. 103-322, 108 Stat. 1796 (codified as amended in scattered sections of title 18 of United States Code).

51 See Harry A. Chernoff et al., The Politics of Crime, 33 HARv. J. ON Legis. 527 passim (1996) (discussing the interaction of the parties leading to the passage of the act).

52 See supra note 48 . Applying the $\chi^{2}$-test produces the probability that chance explains the difference between Justice Broussard's voting and that of the other justices on the court, both of which are under $0.0001 \%$. 
A third hypothesis that might explain Broussard's votes is that they track changes in the law. The relevant law for our sample is the criminal procedure of capital trials in California. One important change was the reversal by the Lucas court of a rule formed by the Bird court. The Bird court held that a jury must find intent to kill in the offense which constitutes the "special circumstance" that produces eligibility for the death penalty. ${ }^{53}$ In other words, if the special circumstance offense is arson, in the commission of which the defendant murdered the victim, the jury must find that the arson was intended for the purpose of murder. The Lucas court reversed that interpretation and affirmed capital sentences of defendants who did not intend to kill with the special circumstance offense. ${ }^{54}$ Although Justice Broussard's voting record might seem to indicate that it tracked changes in the law, when a slightly different fact pattern arises, he dissents and points out paradoxes:

[I]t is irrational to hold this defendant is subject to the death penalty because he initially intended to set a fire to drive the victim from the house and then shoot him, when a defendant who from the beginning intended to burn the victim to death in the conflagration would not be subject to the death penalty, and neither would a defendant who planned to shoot the victim first and then burn down the house to conceal the murder. The death penalty should not turn on such a narrow, technical and insignificant distinction as that invoked as a basis for the majority opinion. ${ }^{55}$

Justice Broussard refuses to acquiesce in an affirming opinion he deems irrational. Despite that the number of his votes affirming the death penalty indicate a change parallel to the change in law, a closer look resists that explanation.

In sum, Justice Broussard changes his voting, refuting self-consistency. His change is too small, however, for a pure explanation on the basis of party affiliation and, although the change is consistent with an intervening change in the law, it is also in tension with that explanation. Justice Broussard seems to reluctantly take an accommodating stance in the Lucas court, which is not easily explained. This question is particularly interesting if we contrast Justice Lucas' accommodating period before the elections. Given the attitudes of the electorate, Justice Lucas'

53 See People v. Whitt, 36 Cal. 3d 724 (1984); Carlos v. Superior Court, 35 Cal. 3d 131 (1983).

54 See People v. Anderson, 43 Cal. 3d 1104, 1138-39 (1987).

55 People v. Clark, 50 Cal. 3d 583, 643-44 (1990) (in the omitted footnote, Justice Broussard adds "it is absurd for a defendant who kills unintentionally to be subject to the death penalty when a defendant who intended to kill is ineligible $f$ punishment”). 
abandonment of his conciliatory stance for confrontation proved effective. The political reality was that Broussard could not expect such a reward for confrontation. He was choosing a middle line between his individual sense of justice and collegial accommodation that frustrates statistical analysis.

\section{B. Justice Mosk}

Contrary to Justice Broussard, who changed his voting in the direction of the court, Justice Mosk made no such concessions. In the 19841985 court, he was the second most affirming judge of the death penalty, after Justice Lucas. Justice Mosk cast affirming votes in $48 \%$ of death penalty cases.

On the 1989-90 court, Justice Mosk's votes to affirm death penalties became increasingly scarce, since he affirmed only $40 \%$ of cases involving the death penalty in that period. Contrary to their differences in 1984-1985 when Justice Mosk was affirming more often than the neveraffirming Justice Broussard, in 1989, Justice Mosk affirmed death penalty cases at the same rate as Broussard. The reduction of Mosk's affirmance record is not statistically significant. Yet, in both periods, Justice Mosk's record also differs significantly from that of the Court.

The contrarian strategy of Justice Mosk is not easy to justify. Frequent disagreements are bound to erode a judge's good will among colleagues and surrender power to influence the majority's opinions. A closer look reveals that Justice Mosk's disagreements produces opportunities to write dissenting opinions.

In 1989-90, Justice Mosk agreed with Justice Broussard 48 times out of 52 cases. In 29 cases, they agreed to reverse the lower court's imposition of the death penalty. In 18 of these reversals they disagreed with the majority of the court. Only in two cases did Justice Mosk vote to reverse without the agreement of Justice Broussard.56 Justice Mosk wrote eight of their joint dissents, ${ }^{57}$ while Justice Broussard wrote two. ${ }^{58}$ Eight more times they both dissented and wrote separately. ${ }^{59}$ Thus, Justice Mosk wrote 16 opinions in the 18 death penalty cases in which he (1990)

56 People v. Andrews, 49 Cal. 3d 200 (1989); People v. Ramirez, 50 Cal. 3d 1158

57 People v. Wright, 52 Cal. 3d 367 (1990); People v. Haskett, 52 Cal. 3d 210 (1990); People v. Bloom, 48 Cal. 3d 1194 (1989); People v. Sheldon, 48 Cal. 3d 935 (1989); People v. Allison, 48 Cal. 3d 879 (1989); People v. Morales, 48 Cal. 3d 527 (1989); People v. Johnson, 47 Cal. 3d 1194 (1989); People v. Robertson, 48 Cal. 3d 18 (1989).

58 People v. Turner, 50 Cal. 3d 668 (1990); People v. Burton, 48 Cal. 3d 843 (1989).

59 People v. Gonzalez, 51 Cal. 3d 1179 (1990); People v. Medina, 51 Cal. 3d 870 (1990); People v. Whitt, 51 Cal. 3d 620 (1990); People v. Sanders, 51 Cal. 3d 471 (1990); People v. Mattson, 50 Cal. 3d 826 (1990); People v. Clark, 50 Cal. 3d 583 (1990); People v. Bell, 49 Cal. 3d 502 (1989); People v. Murtisaw, 48 Cal. 3d 1001 (1989). 
dissented. When they both agreed with the court, Justice Mosk wrote six concurring opinions that Broussard joined, ${ }^{60}$ while Mosk only joined in one concurring opinion authored by Broussard. ${ }^{61}$ Mosk disagreed with Broussard twice to write a dissent, ${ }^{62}$ one while Broussard wrote for the court, ${ }^{63}$ and he wrote six concurring opinions without Broussard, five of which affirmed the death penalty. ${ }^{64}$ Broussard wrote a dissent in one of those cases. ${ }^{65}$ Clearly, Justice Mosk wrote a disproportionate share of the dissenting and concurring opinions in 1989-90.

The picture in 1984-1985 is somewhat different, but again Justice Mosk produced a disproportionate number of dissenting and concurring opinions. Although Justice Lucas agreed with Justice Mosk in 9 dissents $^{66}$ (all affirming the death penalty), of the 15 times they agreed, they often disagreed in their rationale. Lucas and Mosk dissented separately in six cases, ${ }^{67}$ with Lucas joining Mosk in one, ${ }^{68}$ both joining Grodin in one, ${ }^{69}$ and with Mosk joining Lucas in one. ${ }^{70}$ Mosk dissented alone in five cases, ${ }^{71}$ in one additional dissent he was joined by Grodin, ${ }^{72}$ and in one he joined Grodin. ${ }^{73}$ All told, Mosk wrote 13 dissenting opinions out of the 16 cases in which he dissented. Mosk also wrote one concurring opinion $^{74}$ and joined in a concurring opinion of Chief Justice Bird. ${ }^{75}$

60 People v. Kelly, 51 Cal. 3d 931 (1990); People v. Douglas, 50 Cal. 3d 468 (1990); People v. Lewis, 50 Cal. 3d 262 (1990); People v. Jackson, 49 Cal. 3d 1170 (1989); People v. Lang, 49 Cal. 3d 991 (1989); People v. Edelbacher, 47 Cal. 3d 983 (1989).

61 People v. Garrison, 47 Cal. 3d 746 (1989).

62 Peopie v. Ramirez, 50 Cal. 3d 1158 (1990); People v. Andrews, 49 Cal. 3d 200 (1989).

63 People v. Ramirez, 50 Cal. 3d 1158 (1990).

64 People v. Taylor, 52 Cal. 3d 719 (1990); People v. Gallego, 52 Cal. 3d 115 (1990); People v. Stankewitz, 51 Cal. 3d 72 (1990); People v. Carrera, 49 Cal. 3d 291 (1989); People v. Hamilton, $48 \mathrm{Cal}$. 3d 1142 (1989). The sole opinion where Justice Mosk concurs without Justice Broussard is People v. Holloway, 50 Cal. 3d 1098 (1990).

65 People v. Hamilton, 48 Cal. 3d 1142 (1989).

66 People v. Croy, 41 Cal. 3d I (1985); People v. Leach, 41 Cal. 3d 92 (1985); People v. Balderas, 41 Cai. 3d 144 (1985); People v. Hamilton, 41 Cal. 3d 211 (1985); People v. Silbertson, 41 Cal. 3d 296 (1985); People v. Hamilton, 41 Cal. 3d 408 (1985) People v. Massie, 40 Cal. 3d 620 (1985); People v. Fuentes, 40 Cal. 3d 629 (1985); People v. Brown, 40 Cal. 3d 512 (1985).

67 People v. Croy, 41 Cal. 3d 1 (1985); People v. Balderas, 41 Cal. 3d 144 (1985); People v. Davenport, 41 Cal. 3d 247 (1985); People v. Silbertson, 4l Cal. 3d 296 (1984);

People v. Hamilton, 41 Cal. 3d 408 (1985); People v. Fuentes, 40 Cal. 3d 629 (1985).

68 People v. Leach, 41 Cal. 3d 92 (1985).

69 People v. Hamilton, 41 Cal. 3d 211 (1985).

70 People v. Massie, 40 Cal. 3d 620 (1985).

71 People v. Alcala, 36 Cal. 3d 604 (1984); People v. Lanphear, 36 Cal. 3d 163 (1984); People v. Harris, 36 Cal. 3d 36 (1984); People v. Davenport, 41 Cal. 3d 247 (1985); People v. Frierson, 39 Cal. 3d 803 (1985).

72 People v. Memro, 38 Cal. 3d 658 (1985).

73 People v. Lucky, 41 Cal. 3d 315 (1985).

74 People v. Holt, 37 Cal. 3d 436 (1984).

75 People v. Garcia, 36 Cal. 3d 539 (1984). 
Even without having someone join in his dissents as consistently as Broussard did in 1989-90, Justice Mosk already had written many opinions in 1984-1985. Whereas Broussard's appeasement may have sought his colleagues' good will, it seems Mosk's writing seeks the esteem of the legal profession generally.

A recent study of judicial incentives labels judges who seek citations "superstars" and surmises they are few:

[T] he market for opinions (or, more accurately, the market for citations) will be dominated by a few superstars. . . . [I]if a few judges write opinions that are better . . . in enough different areas, only the opinions of these judges will be cited. In addition, there is a skew at the outset. There are a handful of judges who far exceed the others. . . .76

The paucity of superstars, argue Professors Bainbridge and Gulati, induces other judges to use shortcuts to reduce their authorship load. They distinguish their position from this author's argument that common law judges have a stronger incentive to pursue prestige than civil law judges. ${ }^{77}$ Justice Mosk, however, stands as a vivid counter-example to this hypothesis. Mosk was appointed to the Court in September 1964.78 By 1989 he had spent 25 years on the bench. His attaining membership in the "superstar" group was virtually impossible. A search of the pre1989 collection of articles on the LEXIS database produces 85 articles referring to Mosk. ${ }^{79}$ This is a far cry from the true superstar of the California Supreme Court, Justice Traynor, who is cited by 211 pre-1989 articles, or Rose Bird, a search of whose name returns 98 citations. Justice Tobriner, retired since 1981, attracted 53, and Justice Richardson, retired since 1983, attracted 45 citations. ${ }^{80}$ Broussard attracted 12 cita-

76 Bainbridge \& Gulati, supra note 6, at 108-09.

77 Cf. id. at $108 \mathrm{n} .81$ ("In contrast to us, Nicholas Georgakopoulos argues that judges in the U.S. systcm are likely to pursue prestige through the process of opinion writing and specifically through the acquisition of citations."); Nicholas L. Georgakopoulos, Independence in the Career and Recognition Judiciary, 7 ChICAGo Roundtable 205, 212-13 (2000) (comparing the incentives of judges in career-oriented systems and recognition based systems like the federal judiciary; noting that judges may "either . . . shirk their judicial work or . . . use their judicial work to enhance their welfare" but also surmising that "judges in recognition systems may be sufficiently induced not to shirk.").

78 Supreme Court of California, Internal Operating Practices and Procedures of the California Supreme Court 56, available at http://www.courtinfo.ca.gov/courts/supreme/documents/ supreme2003-2.pdf (July 17, 2002).

79 Produced by the command search "2ndary; allrev; ("stanley mosk" or "mosk, stanley") and date(bef 1989)." Some searches produced a handful of articles that did not apply to the appropriate judge; those have been dropped from the counts.

80 See Supreme Court of California, supra note 80 , at 56 available at http:// www.courtinfo.ca.gov/courts/supreme/documents/supreme2003-2.pdf. Mathew Oscar Tobri- 
tions, and Lucas attracted 20. Mosk is third on this list despite lengthy service. In 1989, he must have known that more opinions would not produce a citation count that would overtake Traynor's. Despite the impossibility of achieving the status of "superstar," Mosk wrote tirelessly.

A more sinister explanation of Justice Mosk's high affirmance rate before his 1986 re-election might be that he sought to appease the electorate's preference for the affirmation of cases where the death penalty was imposed. The comparison does not reach statistical significance. It is interesting to note, however, that the change in the law after the election works against the statistical test. Since the law became more forgiving of trial error, the $40 \%$ affirming rate of Mosk on the Lucas court may be partly explained by the change in the law. Furthermore, Mosk's affirming rate from 1981-82 can be used as one more benchmark. In that period he voted to affirm twice ${ }^{81}$ and to reverse seven times, ${ }^{82}$ for an affirmance rate of $22 \%$. This lends some credence to the notion that his pre-election affirmance rate was high but the setting defies statistical validation.

In sum, Justice Mosk was extraordinarily motivated in writing opinions, despite that he could not reach the status of a superstar judge. He might also have been responding to the preferences of the electorate prior to his re-election.

\section{Justice Lucas}

Immediately following his 1984 appointment to the court, Justice Lucas' first votes were in agreement with the Court. Soon thereafter, however Justice Lucas turned into a consistent dissenter. In 1989-90, as the Chief Justice, he still affirmed more death penalty convictions than the entire Court, but affirmed less frequently than in 1989-90.

In 1984, Justice Lucas participated in four death penalty cases and he affirmed only once. ${ }^{83}$ In 1985 he stated that he disagreed with the precedent from 1983 and 1984 which forced the reversal of all cases where: (1) the intentional murder took place during a crime that is a special circumstance according to $\S 190.2$ of the California Penal Code, but where the jury was not instructed that the "special circumstance" crime had to be undertaken with the intent to murder; ${ }^{84}$ and (2) there was

ner served from July 1962 to January 1982; Frank K. Richardson served from December 1974 to December 1983.

81 People v. Robertson, 33 Cal. 3d 21 (1982); People v. Easley, 33 Cal. 3d 65 (1982).

82 People v. Ramos, 30 Cal. 3d 553 (1982); People v. Haskett, 30 Cal. 3d 841 (1982); People v. Hogan, 31 Cal. 3d 815 (1982); People v. Stankewitz, 32 Cal. 3d 80 (1982); People v. Gzikowski, 32 Cal. 3d 580 (1982); People v. Chadd, 28 Cal. 3d 739 (1982); People v. Harris, 28 Cal. 3d 935 (1982); People v. Murtishaw, 29 Cal. 3d 733 (1982).

83 People v. Whitt, 36 Cal. 3d 724 (1984).

84 See id. 
a mention to the jury of the governor's power to commute life sentences. ${ }^{85}$ Lucas dissented in his first death penalty case, People $v$. Whitt ${ }^{86}$ on August 27, 1984. He voted to affirm the death penalty where the jury was not instructed that the "special circumstance" offence-a robbery, in the commission of which a murder took place-had to include intent to kill:

I am convinced by the analysis contained in Justice Richardson's dissent in [Carlos] that ... neither the framers of nor the voters for the 1978 death penalty initiative contemplated the new law would require proof of an intent to kill in a felony-murder situation. . . Believing as I do that Carlos was incorrectly decided, a fortiori, I would not apply that case retroactively to all cases pending on appeal [as required by People v. Garcia, 36 Cal. 3d 539 (1984)]. ${ }^{87}$

With this statement, the relation between Justice Lucas and the Bird court became confrontational. He voted with the court to reverse three death penalty sentences during 1984 . In one case, Justice Lucas wrote a concurring opinion referring to his dissent in Whitt, increasing his distance from the other justices on the court. ${ }^{88}$ Nevertheless, Lucas felt bound by precedent and voted to reverse the death penalty conviction. The same concurrence, under compulsion of precedent that he faulted, appeared in his first and second death penalty decisions in $1985 .{ }^{89} \mathrm{He}$ soon took a more active stance. In an opinion on November 18, 1985, he dissented, stating:

Although I have in the past concurred in reversals of some capital cases under the compulsion of Carlos/Garcia, I can no longer characterize myself as "concurring" in these reversals. . . . I would join three of my colleagues in reexamining, and ultimately overruling, those decisions. ${ }^{90}$

With those words, Justice Lucas abandoned attempts at harmony with the Bird court. He cast ten more votes in 1985, all to affirm the death penalty. ${ }^{91}$

85 People v. Ramos, 37 Cal. 3d 136 (1984) (Lucas, J., concurring).

$8636 \mathrm{Cal} .3 \mathrm{~d}$ at 749.

87 Whitt, 36 Cal. 3d at 749-50 (1984) (Lucas, J., concurring and dissenting) (citations omitted).

88 People v. Ramos, 37 Cal. 3d 136, 159-160 (1984).

89 People v. Anderson, 38 Cal. 3d 58, 62-3 (1985); People v. Hayes, 38 Cal. 3d 780, 788 (1985).

90 People v. Guerra, 40 Cal. 3d 377, 390 (1985) (citations omitted).

91 People v. Brown, 40 Cal. 3d 512, 546 (1985); People v. Fuentes, 40 Cal. 3d 629, 642 (1985); People v. Massie, 40 Cal. 3d 620, 626 (1985); People v. Hamilton, 41 Cal. 3d 408, 437 
In 1989-90, Justice Lucas, rather than casting minority votes to affirm, was Chief Justice of a court that affirmed $79 \%$ of the death penalty sentences it reviewed. The court over which Lucas presided had eroded the principles that he opposed on the Bird court. The Carlos and Garcia holdings were reversed..$^{92}$ The mention of the governor's power to commute life sentences no longer led to per se reversal. ${ }^{93}$ Despite the high proportion of decisions affirming the death penalty in 1989-90, Chief Justice Lucas voted to affirm three more death penalties than the rest of the court. ${ }^{94} \mathrm{He}$ wrote a dissent from one reversal ${ }^{95}$ and joined dissents in the other two. ${ }^{96}$ In one affirming opinion, he wrote a concurring opinion in order to avoid review by the United States Supreme Court. ${ }^{97}$

In sum, the voting patterns of Justice Lucas show that in 1984-85 he attempted to follow the court, then abandoned that stance to confront the court, and finally, in 1989, led the court in affirming death sentences. Justice Lucas' votes, however, like those of Broussard and Mosk, do not yield to statistical analysis. Strategic action is revealed by exploring the totality of the circumstances, not only voting but also items such as the text of each judge's opinions, and the frequency of his dissents. This is an important message for any quantitative study of judges. The exercise of the judicial function leads naturally and inescapably to strategic action that may not be visible in the voting record.

\section{JUDICIAL TENURES}

The consequences of the 1986 election must be studied more closely because they are important in evaluating judicial elections. A complete evaluation of such a complex institution is impossible here. The 1986 elections are particularly conducive to the study of one aspect of this institution, the tension between judicial independence and accountability.

The events of the 1986 California judicial elections can also be rephrased in terms of independence and accountability. The Court's refusal to impose the death penalty was an exercise of its independence. Accountability was achieved through the removal of three justices.

(1985); People v. Deere, 41 Cal. 3d 353, 370 (1985); People v. Silbertson, 41 Cal. 3d 296, 313-314 (1985); People v. Hamilton, 41 Cal. 3d 211 (1985); People v. Balderas, 41 Cal. 3d 144, 206-208 (1985); People v. Leach, 41 Cal. 3d 92, 112 (1985); People v. Croy, 41 Cal. 3d 1, 25-26 (1985).

92 See People v. Anderson, 43 Cal. 3d 1104, 1138-39 (1987).

93 See, e.g. Hamilton, 45 Cal. $3 \mathrm{~d}$ at 375 (holding that, despite the impropriety of mentioning the governor's power to commute sentences during jury instruction, its mention was not prejudicial error).

94 People v. Wright, 48 Cal. 3d 168 (1989); People v. Edelbacher, 47 Cal. 3d 983 (1989); People v. Farmer, 47 Cal. 3d 888 (1989).

95 Edelbacher, $47 \mathrm{Cal}$. 3d at 1043.

96 People v. Wright, 48 Cal. 3d 168 (1989); Farmer, 47 Cal. 3d at 936.

97 See People v. Bloom, 48 Cal. 3d 1194, 1232-1234 (1989) (Lucas, J., concurring). 
The California Constitution gives to the electorate the power to hold justices accountable by removing them. This constitutional power does not exist in jurisdictions where the judiciary has life tenure. Jurisdictions that elect judges in contested elections also confer to their electorate this constitutional power of holding judges accountable, albeit to different degrees.

It is unnecessary to ascertain the degree to which other systems of judicial elections confer such a power. It is important to realize that accountability through elections can be analyzed as a continuum. At one extreme would be systems with contested and very frequent elections; at the opposite extreme would be an irrevocable life tenure system. California's confirmation elections with long terms are a point in that range.

The level of accountability is part of the background institutional structure in which a judge's career unfolds. Compare a judgeship that entails frequent electoral battles to a judgeship with life tenure. Most jurists would consider that the two careers have significant differences, at least in that the latter does not involve any campaigning. Retention elections reduce campaigning compared to contested elections. This creates some similarity to life tenure for judges elected under retention elections. The risk to the career of judges who have life tenure is less than under retention elections. Contested elections produce greater risk.

A complete exploration of the effect of career risk on the judiciary is beyond the scope of this article. Further research may validate a hypothesis that career risk makes the judiciary less appealing to top legal talent. By contrast, perhaps career risk may act as an incentive, and induce elected judges to be more productive and shirk less.

Judges who were appointed to the California Supreme Court before the 1986 elections joined a Court that had never suffered removal of any justice by election. ${ }^{98}$ The removals of justices by election in 1986 may have changed the perceived career risk of the justices and may have changed the selection criteria for appointing judges to the Court. Such a change, whether temporary or permanent, may have the consequence of altering career lengths. If a strong effect is found, further research must focus on the causal link between the elections and career lengths.

The Court has published the dates of appointment and retirement of all justices since its inception, allowing for the rigorous study of career lengths. ${ }^{99}$ It is not surprising to observe that the justices that were removed in 1986 had unusually short tenures. Strikingly, the justices who replaced them and Justice Lucas also had unusually short tenures.

98 See Grodin, supra note 14 and accompanying text.

99 The Supreme Court of California, available at http://www.courtinfo.ca.gov/courts/supreme (reporting the dates of appointment and retirement by month, the day was obtained when available from the archives of the Secretary of State of California). 
California has appointed 111 justices. The sample consists of their career lengths. Ignoring those of the three-member court that existed until 1863 and those who were removed in 1986 leaves 93 careers. ${ }^{100}$ of those, seven correspond to the current court members. The average career duration of the 80 judges appointed before Lucas is 15.6 years with a standard deviation of 11.2. The average career duration of the 13 justices appointed since Justice Lucas is 7.4 years with a standard deviation of 4 . Despite the small sample, the $t$-test ${ }^{101}$ indicates strong statistical confidence in the conclusion that since Lucas careers are shorter. ${ }^{102}$ The difference can also be illustrated by asking how long the current justices should stay on the court for the average tenure since Lucas to reach the pre-election average. All seven Justices must remain on the court until mid March 2016. By that time they will all have served more than 17 years and be in unusually advanced age.

Again, a figure reveals more texture than a statistical test. A figure can show how the length of careers changes over time. It may reveal patterns that are not discernible in raw numbers.

\section{FIGURE 3: TENURE LENGTH OVER TIME}

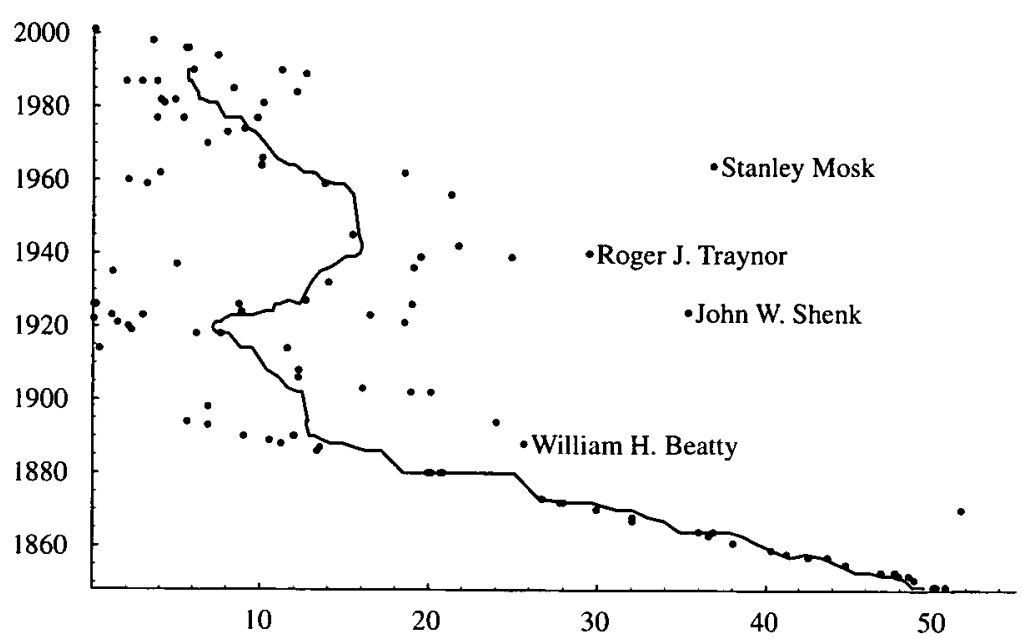

100 The three-member court that existed from 1849 until 1862 had even longer tenures. The justices who were removed in 1986 must be excluded in a comparison of career lengths because the shortness of their careers was extraordinary. The statistical significance of the comparisons below would be even greater if the three-member court was included in the preelection group and the removed justices in the other group. The pre-election sample aggregates the three periods served by Justice Jackson Temple into a single period.

101 See supra note 39.

102 This comparison includes the justices who are still serving on the court and assumes they serve through 2003. Even if they are excluded, confidence can still be had in the statistical evidence. In both cases, the confidence reaches above the $99.9 \%$ level. 
Figure 3 is a graphical representation of the evolution of tenures. The Justices' tenures are measured along the horizontal axis in years, and the year of their appointment is on the vertical axis. Each point captures the year of appointment and the duration of the career of one justice. For example, consider the point that corresponds to Justice Stanley Mosk. Going from it down to the duration axis shows that he served about 37 years. Tracing the same point to the year's axis indicates he was appointed in about 1964.

The figure also indicates by name four of the longest-serving justices and traces a line of the running average of career durations. The calculation of the running average takes into account nineteen careers, nine before and after each justice. Careers that are more distant receive diminishing weight. Thus, the running average shows the tendencies of career durations over time. The longer tenures before the appointment of Lucas in 1984 are apparent. The figure also reveals, however, that similarly short careers existed before. The justices appointed from 1910 to 1930 seem to also have had short careers.

Statistical analysis cannot indicate the cause of the shortening of tenures after the appointment of Justice Lucas and from 1910 to 1930. In both periods, however, a major political change may be at the source of the short careers. Whereas this Article focused on the death penalty battle on which the 1986 elections turned, the emergence of the welfare state and the New Deal may be related to the short careers from 1910 to 1930. More research in this area is necessary. It is plausible that Justice Lucas and those appointed after him were agents of change rather than long-term judges with a tendency not to remain long on the court. A successful change may also reduce the appeal of the court for the Justices who predate the change. A case study of the court in the first half of the twentieth century would answer some of these questions.

\section{CONCLUSION: IMPOSSIBLE EVALUATIONS?}

This Article studied the death penalty votes and opinions of the three justices that spanned the 1986 elections. Their conduct defies easy explanation. It remains the conduct of three individuals, whose true motivations cannot be fully known.

The examination of these three judges reveals three very different, yet very rich, judicial and political strategies. Justice Broussard demonstrated how a dissenter can work with a majority of the court without confrontation and perhaps with the hope of some influence. Justice Mosk is an example of a judge dedicated to the craft of writing opinions, despite that he cannot attain star status. Justice Lucas' record shows how a confrontational dissenter may turn into the leader of a new court, if the political environment is favorable. 
The 1986 elections consummated a major change in policy about the death penalty. The removal of justices by election was an extraordinary event that may have altered the actual or perceived risk of removal. Indeed, the lengths of the post-election careers are unusually short. A similar shortness appeared approximately from about 1910 to 1930 . The large political change at those two times opens the possibility of identifying periods of political change by shortened judicial careers. 